THE JOURNAL OF EUROPE - MIDDLE EAST SOCIAL SCIENCE STUDIES

ISSN: 2149-6439, JANUARY, 2016, VOLUME: 2, ISSUE: 1, S: 1 - 25

WWW.JEMSOS.COM

http://dergipark.ulakbim.gov.tr/jemsos/index

\title{
EFFECT OF WEB-BASED PEER AND SELF-EVALUATION ON STUDENTS' ACHIEVEMENT REGARDING COMMUNICATION AND HUMAN RELATIONS
}

\author{
Adem ÇIRAK $^{* *} \quad$ Nureddin VAN ${ }^{* * *}$
}

\begin{abstract}
The objective of this study is to examine the effect of the web-based peer and Selfevaluation on students' achievement regarding communication and human relations. The assessment instruments that were used are Human Relations Achievement Test (HRAT), Communication and Human Relations Mixed Exam, Communication and Human Relations Mixed Exam Evaluation Form, Peer and Self-evaluation Method Program, Peer and Selfevaluation User Manual. This study was conducted in the first semester of the 2013-2014 academic year with 355 seventh grade students in four secondary schools in Sincan, Ankara. The study included seven teachers and two classes for each teacher. The study on all groups took eight weeks. Descriptive statistics were used by using the data obtained from the preliminary and final tests. Results showed that the distribution of data for each variable was approximately normal. Univariate ANOVA analysis was used as inferential statistics. ANOVA results showed significance in favour of test groups.

Data obtained as a result of the study supported that the web-based peer and Selfevaluation method is effective in increasing students' achievement on communication and

* This study was conducted by Adem Çırak within the scope of the PhD thesis supervised by the Assistant Professor Nureddin Van.

** Dr. Ankara, Turkey. ademcirak55@hotmail.com

${ }^{* * *}$ Asistant Professor, Dumlupınar University, Education Faculty, Department of Teaching of Social Sciences. Kütahya, Turkey.nureddin.van@dpu.edu.tr
\end{abstract}


human relations. When compared to the control group, the results are statistically significant in favour of the students in the test group. The girls are more successful compared to the boys. Teachers' and students' views support the quantitative and qualitative results obtained in the study. According to the survey data, it is concluded that students like the web-based program.

Keywords: Achievement, communication and human relations, web-based peer and self-evaluation. 


\section{INTRODUCTION}

One of the most important stages of education process is the ability to measure the outputs and to evaluate these assessments according to the selected appropriate criteria, as assessment and evaluation explain the final status of the education activity and present significant information on that activity ${ }^{1}$.

Assessment and evaluation is an indispensable part of education and teaching. Changes and constant renewals in the field of education revealed the shortcoming in the evaluation of education and production process as well as the need for renewal. This caused the review of the relation between learning and assessment-evaluation. Alternative assessment and evaluation approaches were put forward as the traditional measurement and evaluation techniques were insufficient to realize the new intended functions. These methods are basically more interactive compared to the traditional assessment and evaluation techniques, deal with the result and process as a whole, is student-centred and highlight the creativity and top level skills of students ${ }^{2}$.

Self-evaluation and peer-evaluation are one of the new approaches that measure the process other than those that are included in the traditional teaching programs and that just measure the product ${ }^{3}$.

\section{PEER-EVALUATION AND SELF-EVALUATION}

Peer-evaluation is the need to evaluate the performances, achievements and learning conditions ${ }^{4}$. Self-evaluation is conducted by the students to measure the learning conditions as a result of their studies within the teaching process ${ }^{5}$.

The use of peer-evaluation is not new and has had an increasingly wider scope of use like the self-evaluation practices ${ }^{6}$. Peer-evaluation is used in all professional competency

\footnotetext{
${ }^{1}$ Turgut, M., \& Baykul, Y. (2012). Eğitimde Ölçme ve Değerlendirme. Ankara: Pegem Akademi.

${ }^{2}$ Bahar, M. (2006). Geleneksel Alternatif Ölçme Ve Değerlendirme. Ankara: Pegem Yayınc1lık.

${ }^{3}$ Sluijsmans, D., Dochy, F., \& Moerkerke, G. (1998). Creating A Learning Environment By Using Self, -Peer- And Co-Assessment. Learning Environment Research, 1, 293-319.

${ }^{4}$ Lindblom-Ylanne, S., Pihlajamaki, H., \& Kotkas, T. (2006). Self, -Peer- And Teacher- Assessment Of Student Essays. Active Learning In Higher Education, 1(7), 51-62

${ }^{5}$ Nartgün, Z. (2006). Fen Ve Teknoloji Öğretiminde Ölçme Ve Değerlendirme. In M. Bahar (Ed.), Fen ve Teknoloji Ögretimi (14. Bölüm). Ankara: Pegem A Yayıncılık

${ }^{6}$ Lindblom-Ylanne et al., Op.cit.
} 
fields and in various fields of higher education from engineering study $^{7}$ to teacher education ${ }^{8}$.

When we want to apply self-evaluation and peer-evaluation, the first method to use is the one that involves paper and pencil as instruments. When we apply the paper and pencil method, we first have a problem with respect to time. Self-evaluation and peer-evaluation process within classroom environment is limited to the length of class ${ }^{9}$. Use of technology was useful in eliminating all these problems. In the electronic system that he developed in order to see how proper can students evaluate themselves without a teacher supervision, Gentle $^{10}$ determined that students were more aware of their quality of their works and reflected this in their attitudes. In addition, this electronic system allowed saving time and students were able to make more than one evaluation reducing the teacher effect.

Gehringer ${ }^{11}$ emphasized that the web use has gained importance in both business life and academic life and students gained the experience of using different programs by the use of web-based evaluation systems. Wen and Tsai ${ }^{12}$ conducted a research in Taiwan in order to examine the approaches and attitudes of the university students towards the web-based peer-evaluation. This research involved 280 university students and indicated that the students had positive attitudes towards the peer-evaluation of students and added, however, that the students regarded web-based evaluation as a tool to facilitate peer-evaluation not as an auxiallary factor to assist learning.

According to the understanding of applying assessment and evaluation through new developing technologies would be more appropriate than through known material. An assessment and evaluation program drafted over internet (web-based peer-evaluation and self-evaluation program) is a study that is conducted to realize this function. In addition to

${ }^{7}$ Willey, K., \& Gardner, A. (2010). Investigating The Capacity Of Self And Peer Assessment Activities To Engage Students And Promote Learning. European Journal of Engineering Education, 35(4), 429-443.

${ }^{8}$ Norcini, J. (2003). Peer Assessment Of Competence. Medical Education, 37(6), 539-543.

9 Tsai, C. C., Liu, E. F., Lin, S., \& Yuan, S. M. (2001). A Networked Peer Assessment System Based On A Vee Heuristic. Innovations in Education and Teaching International, 38(3), 220-230.

${ }^{10}$ Gentle, C. (1994). Thesis: An Expert System For Assessing Undergraduate Projects. In M. Thomas, T. Sechrest, \& N. Estes (Ed.), Deciding Our Future: Technological Imperatives For Education (pp. 11581160). Austin

${ }^{11}$ Gehringer, E. (2001). Electronic Peer Review And Peer Grading In Computer-Science Courses. Proceedings Of The Thirty-Second Sigcse Technical Symposium On Computer Science Education (pp. 139243). Raleigh

${ }^{12}$ Wen, M., \& Tsai, C. C. (2006). University Students' Perceptions Of And Attitudes Toward (Online) Peer Assessment. Higher Education, 51, 27-44. 
that, it was determined that every type of self-evaluation and peer-evaluation studies contributed to the improvement of learning and that applying self-evaluation and peerevaluation in combination contributed to the creation of a sharing, critical and reliable test culture particularly in young individuals ${ }^{13}$.

Whether web-based peer-evaluation and self-evaluation are effective methods to increase students' achievement or not is the essence of this study. As a result of a practice conducted through the web-based peer-evaluation system called Peer Grader at the North Carolina State University, it was determined that student assignments got better and that there was statistically significant increase in favour of the test group compared to the control group $^{14}$ which was perhaps the most important result of the studies in this field. Similarly important another issue is that it is vitally significant the teachers should believe that practice would bring good results and provide students with assistance in learning process, as the success of evaluation practices depends on teachers' as well as students' qualities ${ }^{15}$.

In a survey through their online system, $\mathrm{Lu}$ and $\mathrm{Law}^{16}$ approved that the online peerevaluation was useful for the learning process and added that students making the evaluation got more benefit from this process than the evaluated students.

The most crucial point of the study is to understand the effect of web-based peerevaluation and self-evaluation method and teacher practices on students' achievement and therefore our survey works on both matters are important to shed a light on the subject. The objective of this study is to examine the effect of assessment and evaluation through webbased self-evaluation and peer-evaluation on students' achievement regarding the communication and human relations of the $7^{\text {th }}$ grade Social Sciences subject.

${ }^{13}$ Steele, G. (2009). Self And Peer Assessment In An Undergraduate Communication Research Class Using Mixed Methods. Augustine Trinidad and Tobago: Department of Liberal Arts.

${ }^{14}$ Gehringer, Op.cit.

${ }^{15}$ Lewkowicz, J., \& J. Moon. (1985). Evaluation: A Way Of Involving The Learner. In Evaluation: Lancaster Practical Papers In English Language Education (pp. 45-80). Oxford: Pergamon Press.

${ }^{16}$ Lu, J., \& Law, N. (2012). Online Peer Assessment: Effects Of Cognitive And Affective Feedback. Instructional Science, 40, 257-275. 


\section{THE PROBLEM OF THE STUDY}

What is the effect of the evaluation activities through web-based peer-evaluation and self-evaluation on students' achievement regarding the communication and human relations of the $7^{\text {th }}$ grade Social Sciences subject.

\subsection{SUB PROBLEMS:}

- Are the evaluation activities through web-based peer-evaluation and self-evaluation effective on students' achievement regarding the communication and human relations of the $7^{\text {th }}$ grade Social Sciences subject?

- Are the evaluation activities through web-based peer-evaluation and self-evaluation effective on students' achievement regarding the communication and human relations of the $7^{\text {th }}$ grade Social Sciences subject based on the gender of the students?

- Are the evaluation activities through web-based peer-evaluation and self-evaluation effective on students' achievement regarding the communication and human relations of the $7^{\text {th }}$ grade Social Sciences subject based on the views of teachers and students?

\section{METHOD}

The study has a mix research design where quantitative data was obtained by using a semi-experimental method and qualitative data was obtained by using teacher and student survey. Mixed method provides better understanding of a certain phenomenon by using qualitative and quantitative methods in combination ${ }^{17}$.

In education systems, like ours, where centralized education is used and researchers are not able to create classes through random assignment, classes that were previously created by school managements are determined randomly as test and control group ${ }^{18}$. Test and control groups were determined randomly by draw to specify which one of the two classes of teachers will be test group and which one will be control group. Preliminary test is applied to both of the groups and only test group is subject to experimental intervention while final test is applied to both groups ${ }^{19}$.

${ }^{17}$ Gay, L. R., Mills, G. E., \& Airasian, P. (2009). Educational Research: Competencies For Analysis And Application (9th ed.). USA: Pearson.

${ }^{18}$ Çepni, S. (2012). Araştırma Ve Proje Çalışmalarına Giriş. Trabzon: Celepler Matbaacılık.

${ }^{19}$ Karasar, N. (2005). Bilimsel Araştırma Yöntemi. Ankara: Nobel Yayıncılık. 
Preliminary test/final test semi experimental design was used in the quantitative part of the study. Qualitative part included semi-structured interviews with students applying evaluation survey including open-ended questions. Content analysis method in qualitative data is a method to code data, to organize codes into categories and to create themes according to the meanings of categories ${ }^{20}$.

Analysis of quantitative data was done by using the ANOVA and t-test while the analysis of qualitative data was done by using content analysis method. Evaluation survey was applied to determine whether the qualitative data support the findings obtained by quantitative data or not.

\subsection{UNIVERSE AND SAMPLE}

The study was conducted in the Sincan, a central district of Ankara. Information Technology Classrooms (ITC) are required in the schools where the study will be applied. 18 of the 38 schools included ITC classrooms. 7 schools were determined as not having sufficient number of computers. After that, 4 schools complying with the requirements were randomly selected among 11 schools. It was determined that there were 1484 students in the schools with ITC while there were 5683 secondary school students in the district of Sincan. The ratio of the number of students participating in the study to the number of total students in the schools covered by the study corresponds to the $25 \%$ of the universe. In addition, 7 of the voluntary teachers were determined after ensuring required permissions.

\subsection{ASSESSMENT INSTRUMENTS}

As an assessment instrument in the study, Communication and Human Relations Achievement Test was used to assess the achievements of the students. For the students to apply peer-evaluation and self-evaluation, Communication and Human Relations Mixed Exam, Communication and Human Relations Mixed Exam Evaluation Form, Peerevaluation and Self-evaluation Method Program, Peer-evaluation and Self-evaluation User Manual were used.

${ }^{20}$ Mcmillan, J. H., \& Schumacher, S. (2010). Research In Education: Evidence-based Inquiry. New York: Pearson Publishing. 


\subsection{TEACHING AND EVALUATION MATERIALS}

A test including the targeted concepts to be taught was created in the web-based peerevaluation and self-evaluation program. Questions were drafted from the communication and human relation subject based on the attainment defined by the Ministry of National Education (MEB). Questions consisted of open-ended, true-false and gap filling categories. This test intends to assess the understanding and grasping level of communication and human relations subject. This test was conducted to students at BTS. Web-based peerevaluation and self-evaluation program was used to draft the assessment form of the mixed examination on the desired subject content. This form included 15 questions from different categories on the selected subject. A user manual was drafted for the correct and easy use of the web-based peer-evaluation and self-evaluation system.

\section{PRACTICE}

The schools in the Sincan district to conduct the study in were determined and official permissions were obtained. Interviews were done with the experienced Social Sciences teachers to obtain information on the question types that need to be included in the achievement test. Achievement test draft was prepared on the basis of attainment content and shown to three Social Sciences teachers who are competent in their fields. Based on the feedback from the experts, achievement test changes were done and the preliminary pilot and pilot applications were done. The test was brought to the final version after changes according to the item analysis results. Social Sciences teachers of the sample classes were informed about the content, process and program of the study and preliminary tests were applied before processing the study subject to the test and control groups. After processing the subject by teachers, new classes were determined by random method from every school as test groups. The information of the students in these classes was entered to the peerevaluation method. This started application of studies in specified schools. After the subject is completed, the test was defined to the test group students on the program. Students in the test group was allowed to carry out these tests on the "web-based peer-evaluation and selfevaluation" program. This program provided every student in the test group with a user name and password with the guidance of user manual. Every student was asked to evaluate his/her own test and the tests of two friends in the program and to score the tests. The second part required them to respond to the questions on the software. 


\subsection{DATA ANALYSIS}

Qualitative data was analysed in the SPSS program. First of all, descriptive statistics of data were examined. Here first their achievement test averages were compared and it was discussed whether they distribute data normally or not. T-test was used to examine the effect of gender in inferential statistics and ANOVA analysis was used to determine whether the method made a difference or not.

The qualitative data obtained was interpreted by the content analysis method. The responses of teachers for each question were encoded and categories were created from codes reaching to three themes from these categories. Similarly, the responses of the students were also encoded and categorized to create three themes from these categories. In addition, examples of teacher and student views were given under each theme.

\subsection{INTERNAL VALIDITY OF THE STUDY}

Experimental studies include threats for internal validity like selection of participants, maturity, regression selection method, participant loss, widespread experimental process, reaction to experimental process, competition, assessment conditions and assessment instrument; and threats for external validity like interaction between experimental processes, experiment environment and participant history ${ }^{21}$. This research includes measures to remove threats for internal validity.

In the selection of participants, test and control groups were ensured to meet external events equally other than the method. Practice was done in 4 different schools including both test and control groups in every school. That is, effect from external incidents and random incidents were equal in the test and control group. Sample on the threat of participant loss was kept very wide. The results of preliminary test evaluation of the students who didn't participate in the final test were removed from the test. At the same time, participant loss was very limited (3 people). In our study on the selection method and regression threat, 4 of the schools including ITC classroom and the test and control classes in these schools were randomly selected. Maturation threat is not sufficient for this research as the study took 8 hours in total from preliminary test to the receipt of final test results.

${ }^{21}$ Creswell, J. W. (2012). Araştırma Deseni (S. B. Demir, Trans.). Ankara: Eğitim Kitap Yayıncılı̆̆ı. 
To isolate the test group from external factors, communication between the test and control groups towards the threat of mainstreaming experimental processes and towards the reaction was minimized. In addition, assistance was provided to teachers for implementing the method to the students in the control group when the work was completed. Talks were made with students in the control group towards the competition threat and it was stipulated that a period of 8 weeks should pass between the preliminary test and final test so that the questions of achievement test on assessment condition threat were not familiar to students. The assessment instrument threat is not valid for this study as the same achievement test was used for the preliminary test and final test.

In this study, generalization was made with respect to similar students, similar environments and similar time periods in the results of the study by taking into consideration the participants' history, experiment environment and experimental processes. 


\section{FINDINGS}

This section includes analyses on findings, descriptive statistics, inferential statistics, One-Way Anova results, findings obtained from qualitative data (teacher and student survey results).

\subsection{FINDINGS OF FIRST HYPOTHESIS}

This section includes the normal distribution and averages of the data obtained by assessments through descriptive statistics.

Table 1: Descriptive Statistics Related to Preliminary Test Responses Total (PTR TOT) Values and Final Test Responses Total (FTR TOT) Values

\begin{tabular}{|c|c|c|c|c|c|c|}
\hline & $\mathrm{N}$ & Minimum & Maximum & Average & Standard & Skewness \\
\hline & & & \multicolumn{4}{|c|}{ Deviation } \\
\hline $\begin{array}{c}\text { PTR } \\
T O T\end{array}$ & 335 & 0 & 30 & 18,81 & 6,305 &,- 301 \\
\hline $\begin{array}{l}\text { FTR } \\
\text { TOT }\end{array}$ & 335 & 6 & 31 & 21,74 & 6,100 &,- 588 \\
\hline \begin{tabular}{ll} 
& \multicolumn{2}{c}{$P T R$} \\
Test & TOT
\end{tabular} & 165 & 5 & 30 & 18,20 & 6,350 &,- 319 \\
\hline Group $_{\text {TOT }} F T R$ & 165 & 8 & 31 & 22,82 & 5,873 &,- 679 \\
\hline $\begin{array}{ll} & P T R \\
\text { ControlTOT } & \end{array}$ & 169 & 0 & 30 & 19,41 & 6,221 &,- 282 \\
\hline Group $_{\text {TOT }} F T R$ & 170 & 6 & 30 & 20,69 & 6,148 &,- 521 \\
\hline
\end{tabular}

While the average of correct responses of the participants students to the preliminary test questions (PTR TOT) was 18,81 while the average of correct responses to the final test questions (FTR TOT) was 21,74. In the test groups, the preliminary test correct answer average was 18,20 while the final test correct answer average was 22,82. As seen here, there was a net increase of 4,62 in average in the test group. In the control groups, the preliminary test correct answer average was 19,41 while the final test correct answer average was 20,69. As seen here, there was a net increase of 1,28 in average in the control group. Preliminary test and final test averages of the test and control groups increased in favour of the test group. Skewness and kurtosis values were nearly zero in all groups. Therefore, it can be said that the skewness and kurtosis of the distribution is normal. While the PTR TOT skewness average of the test group was $-0,319$ and kurtosis average was $-0,827$; FTR TOT skewness 
average was $-0,679$ and kurtosis average was $-0,526$. While the PTR TOT skewness average of the control group was $-0,282$ and kurtosis average was -0,683; FTR TOT skewness average was $-0,521$ and kurtosis average was $-0,685$. In other words, skewness and kurtosis values of the PTR TOT and FTR TOT results show normal distribution. Another method used to examine the values obtained from the continuous variables is skewness coefficient (SC). Zero (0) values of SC show fully normal distribution while values between -1 and +1 show that there is no important deviation from the normal distribution. When the skewness coefficients of the PTR TOT and FTR TOT values were calculated, the PTR TOT SC was found to be -,566 and FTR TOT SC to be -,619. As shown here, both values were between 1 and +1 . This shows that the PTR TOT and FTR TOT values were distributed normally.

\subsection{FINDINGS OF SECOND HYPOTHESIS}

This section will examine the data obtained from the assessments done with inferential statistics.

Findings obtained according to the gender variable.

The $\mathrm{T}$ test was obtained to examine whether there is a significant change in the data obtained from the PTR TOT values according to the gender of the students. Table 2 includes the independent $t$ test values.

Table 2: $\mathrm{T}$ Test Results of the FTR TOT Scores according to the Gender Variable

\begin{tabular}{|c|c|c|c|c|c|c|}
\hline & Gender & $\mathrm{N}$ & Average & $\mathrm{Sd}$ & $\mathrm{t}$ & $\mathrm{P}$ \\
\hline FTR & Girls & 163 & 22,59 & 5,948 & \multirow[b]{2}{*}{2,498} & \multirow[b]{2}{*}{0,013} \\
\hline $\begin{array}{l}\text { TOT } \\
\text { score }\end{array}$ & Boys & 172 & 20,94 & 6,149 & & \\
\hline
\end{tabular}

When Table 2 was examined, it was seen that gender had a significant change in FTR TOT scores $(\mathrm{p}=0,013<0,05)$. Final test results of girls are higher than boys. Correct score average of girls was 22,59 while that of boys was 20,94 . There was a slight difference in favour of girls. 


\subsection{ONE WAY ANOVA RESULTS}

This study examines the web-based peer-evaluation and self-evaluation on achievement while there is only one dependent variable FTR TOT. Anova analysis is conducted if the values of single dependent variables show normal distribution ${ }^{22}$. The Anova analysis of the FTR TOT results are shown in Table 3.

Table 3: Anova Test Results of the FTR TOT Values

\begin{tabular}{|c|c|c|c|c|c|c|}
\hline & $\begin{array}{l}\text { Sum of } \\
\text { es }\end{array}$ & $\mathrm{df}$ & $\begin{array}{l}\text { Average } \\
\text { es }\end{array}$ & of & $\mathrm{f}$ & $\mathrm{P}$ \\
\hline $\begin{array}{l}\text { Between } \\
\text { groups }\end{array}$ & 382,026 & 1 & 382,026 & & 10,562 &, $001 *$ \\
\hline group & 12044,380 & 333 & 36,169 & & & \\
\hline Total & 12426,406 & 334 & & & & \\
\hline
\end{tabular}

When table 3 is examined, the Anova test results of FTR TOT were found significant $(\mathrm{f}=10,562, \mathrm{p}<0,01)$. Web-based peer-evaluation and self-evaluation had a positive effect on the achievement of students. That is, it can be said that web-based peer-evaluation and selfevaluation increased the achievement of students. When we examine the Table 1 including the descriptive statistics results, the correct answer average of the students in the test group $(22,82-18,20=4,62)$ increased more than that of the students in the control group $(20,69-$ $19,41=1,28)$.

\subsection{FINDINGS OF THIRD HYPOTHESIS}

Qualitative findings obtained from teachers

A survey of three open-ended questions was applied to all of teachers participating in the study to support the quantitative data obtained. Responses to the survey were encoded and categorized. The categories of the responses by teachers to the question "Do you think that the peer-evaluation and self-evaluation program contributed to the learning of the subject by the students?"

${ }^{22}$ Ibid. 
Table 4: Teacher views on the Contribution of Web-based Peer-Evaluation and SelfEvaluation to Learning of the Subject.

\begin{tabular}{lcc}
\hline Categories & f & Percentage \\
\hline It contributes to the learning of the subject by the students & 3 & 42,85 \\
It provides feedback and self-criticism for students & 3 & 42,85 \\
The subject awareness of the students is improved & 1 & 14,28 \\
\hline Total & 7 & 100 \\
\hline
\end{tabular}

3 teachers $(42,85 \%)$ stated that the web-based peer-evaluation and self-evaluation method contributed to learning; 3 teachers $(42,85 \%)$ stated that the students received feedback through peer-evaluation thanks to the method and provided reinforcement of the subject through self-criticism with self-evaluation; 1 teacher $(14,28 \%)$ stated that it created awareness on the subject. Some examples on the teacher views are as following:

K-1: "Yes I do. I believe that awareness on what is learned in the education-teaching process is provided by the peer-evaluation and self-evaluation after the subject is taught."

K-2: "Yes, it is useful to understand how much the subject is learned and what the missing parts are. In addition, it enables student to make self-criticism and correction."

K-3: "Yes, it provides feedback for learning the subjects. Students can see their level and abilities. They learn the rules of working together."

Table 5 includes the categories of the responses of teacher given to the question "What do you think about the system for the students to evaluate themselves and their friends."

Table 5: Teacher Views on the Web-based Peer-evaluation and Self-evaluation Program

\begin{tabular}{lccc}
\hline Categories & f & Percentage \\
\hline $\begin{array}{l}\text { It provides students with opportunity to compare their } \\
\text { mistakes }\end{array}$ & 6 & 85,71 \\
Knowledge awareness provides permanent achievement & 1 & 14,28 \\
\hline Total & 7 & 100 \\
\hline
\end{tabular}

6 teachers $(85,71 \%)$ stated that the web-based peer-evaluation and self-evaluation method provided students with the opportunity to compare their mistake and 1 teacher $(14,28 \%)$ stated that it provided knowledge awareness and permanent achievement. Some examples of the teacher views are as following: 
K-3: "Self-evaluation process realizes an active effort in reaching to correct information to make attainment of this knowledge more permanent. Together with the peerevaluation, they will have the possibility to compare their mistakes to that of their peers and it will enable awareness of their knowledge level.

K-4: "It provides students with the chance to see their mistakes and abilities and enables them to make comparison."

K-5: "It reveals what students learned and what are the problem areas. They become aware of what they learn. They have the chance to improve and discover themselves, to evaluate themselves and friends and to become open to criticize others and to be criticised by others".

K-6: "It is one of the requirements of constructive education. This way, it provides a student centred education which provides healthier and more correct assessment and it is certain that it is more useful than the old system."

Table 6 includes the categories of the responses of teachers to the question "Do you think that the students can easily perform the peer-evaluation and self-evaluation program? What are your suggestions on this subject?"

Table 6: Teacher Views on the Usage Easiness of the Web-based Peer-Evaluation and Self-Evaluation Program

\begin{tabular}{lcc}
\hline Categories & f & Percentage \\
\hline Computer command of students should increase & 3 & 42,85 \\
I think that students do it easily & 3 & 42,85 \\
Teachers are not prepared and they should get in-service & 1 & 14,28 \\
training & 7 & 100 \\
\hline Total & & \\
\hline
\end{tabular}

3 teachers $(42,85 \%)$ stated that computer commands of students should increase; 3 teachers $(42,85 \%)$ stated that students do it easily; 1 teacher $(14,28 \%)$ stated that teachers are not prepared and they should get in-service training. Some examples of teacher views on the subject are as following:

K-1: "I think students with computer commands can do it easily. However, I think that a demonstration and a short practice will enable all students to do it easily." 
K-3: "Students have difficulties as they are new to this assessment system but they will get used to it with the subsequent assessments based on peer-evaluation and self-evaluation as required by our new education system."

K-5: "There will be difficulties in the first practice but continuity will bring practicality as well. In addition, computer command of students is an important factor and students having this competency overcome this process easier. I believe that the demonstration and exemplary practice will make it easier."

K-6: "No, lack of classroom environment makes it difficult. As subjects were intense, no sufficient time was spared to this program. Peer-evaluation may make the program more attractive. Teachers are not open to these subjects and they need to get in-service training. Mostly these evaluations are considered unnecessary."

According to the survey data applied to teachers, it can be concluded that web-based peer-evaluation and self-evaluation program is appreciated by teachers.

\subsection{QUALITATIVE FINDINGS OBTAINED FROM STUDENTS}

In order to support the obtained quantitative data, a survey of three questions open to all of the participating students. Responses to the survey were categorized by encoding. Table 7 includes the categories of the responses by students to the question "peer-evaluation and self-evaluation program".

Table 7: Views of Students on the Ease of Use of the Web-based Peer-evaluation and Self-evaluation Program

\begin{tabular}{lll}
\hline Categories & f & Percentage \\
\hline It was easy to use & 37 & 92,50 \\
I enjoyed it much & 2 & 5 \\
It was very educative & 1 & 2,5 \\
\hline Total & 40 & 100 \\
\hline
\end{tabular}

37 students $(92,50 \%)$ stated that they used the web-based self-evaluation and selfevaluation method; 2 students (5\%) stated that they enjoyed it very much; 1 student $(2,5 \%)$ said that it was very educative. Some examples on students' views are as following:

K-8: "Yes, it was easy and I enjoyed it very much".

K-13: "Yes, it was very easy and fun as well." 
K-17: "Yes, I can easily understand the program. It is very educative at the same time. I personally found it very good and the questions were very simple."

K-28: "It was a little difficult as there were some confusion."

Table 8 includes the categories of the responses by students to the question "Do you think that evaluation of your friends through peer-evaluation and self-evaluation?"

Table 8: Students Views on the Use of Evaluating Friends by the Web-based peerevaluation and self-evaluation

\begin{tabular}{lll}
\hline Categories & $\mathrm{f}$ & Percentage \\
\hline Yes, it was useful & 38 & 95 \\
It allowed me to make comparison & 2 & 5 \\
\hline Total & 40 & 100 \\
\hline
\end{tabular}

38 students (95\%) stated that web-based peer-evaluation and self-evaluation program was useful, $2(5 \%)$ stated that it allowed him/her to make comparison. Some examples of student views are as following:

K-9: "I don't think it is very useful but it allowed me to make comparison."

K-19: "Yes, we can help our friends find their mistakes."

K-21: "Yes, I saw the level of my friends. I noticed the questions they failed and compared to my responses."

K-27: "Yes, I think so. As I notice both my mistakes and those of my friends."

Table 9 includes the categories of the responses given by the students to the question "Do you think that you can see your own shortcomings through the peer-evaluation and selfevaluation program of the student?"

Table 9: Students Views on Seeing their Shortcomings through the Web-based Peerevaluation and Self-evaluation

\begin{tabular}{lll}
\hline Categories & F & Percentage \\
\hline I saw my shortcomings & 32 & 80 \\
I learn the subjects to be reinforced & 8 & 20 \\
\hline Total & 40 & 100 \\
\hline
\end{tabular}


32 students $(80 \%)$ stated that they saw shortcomings with the web-based peerevaluation and self-evaluation program; 8 students (20\%) stated that they could learn the subjects which should be reinforced. Some examples on students' views are as following:

$\mathrm{K}-11$ : "No, as we carry out only tests and evaluations in this program. It is difficult for everyone to participate in this program."

K-25: "Yes, I saw my mistake and I studied harder".

K-34: "Yes, I think so. This way, I learn the subjects, solve more questions and do repetitions."

K-40: "Of course, I saw all my shortcomings. I corrected my mistakes and I reinforce my knowledge in the class."

Total 40 students participated in this survey through random method. According to survey data, it can be concluded that the program was liked by students.

Qualitative data showed that Anova test results analysed by quantitative data are supported by teacher and student views.

\section{CONCLUSION, DISCUSSIONS AND SUGGESTIONS}

This study was conducted to examine the effects of web-based peer-evaluation and self-evaluation method on the achievement of $7^{\text {th }}$ grade students regarding the communication and human relations of the Social Sciences lesson. It was observed with the Anova results that web-based peer-evaluation and self-evaluation method had a positive effect on students' achievements. Data supports that the web-based peer-evaluation and selfevaluation method is an effective one to increase the achievement of students on communication and human relations. It is statistically significant $(\mathrm{p}=0.001<0.05)$ in favour of the test group between the test group and control group. Inferential statistics results show that the students in the test groups are more successful than the students in the control groups. Final test results of the girls are higher than the boys. The correct response average of girls was 22,59 while that of boys was 20,94 . There was a slight difference in favour of girls. Students found the web-based evaluation peer-evaluation and self-evaluation method to be more useful, fun and easier. 
No previous study was found on the web-based peer-evaluation and self-evaluation method regarding the achievement of the $7^{\text {th }}$ grade students on the communication and human relations subject of the Social Sciences lesson. Therefore, it wasn't possible to compare the results of this study with similar studies.

The test group students stated in the survey about the peer-evaluation and selfevaluation program that the system had a positive effect for them to understand the test subject and was also educative, useful, supplementary and fun. They found the interpretation of their tests by their friends to be positive and that it gave them the chance to see their shortcomings. Test group students stated that they were happy when doing peer-evaluation and self-evaluation. This data obtained from the survey is parallel to the findings in the research.

When we discuss our results with the studies within the framework of the web-based peer-evaluation and self-evaluation ${ }^{23}$, perhaps the most important result of the study was that the web-based peer-evaluation and self-evaluation program was an effective method to increase the achievement of students. It was concluded that there was a significant increase in favour of the test group compared to the control group. Our conclusion is supported by the fact that an application at the North Carolina State University through a web-based peerevaluation system called Peer Grader found that the assignements of students got better ${ }^{24}$.

Another remarkable conclusion in their surveys is that the students stated that they found the web-based peer-evaluation and self-evaluation method easy and fun. Having the same result in a project called "Electricity in Our Life", Bozkurt and Demir ${ }^{25}$ found that the

${ }^{23}$ Gehringer, Op.cit.; Wen \& Tsai, Op.cit.; Lu \& Law , Op.cit., Tsivitanidou, O. E., Zacharias C. Z., \& Hovardas, T. (2011). Peer Versus Expert Feedback: An Investigation Of The Quality Of Peer Feedback Among Secondary School Students. Computers \& Education, 71, 133-152.; Falchikov, N. (1995). Peer Feedback Marking: Developing Peer Assessment. Innovations in Education \&Training International, 32(2), 175-187.; Davies, P. (2000). Computerized Peer Assessment. Innovations in Education and Teaching International, 37(4), 346-355.; Huang, S. Y. (1998). A Comparison Between Chinese EFL Students' Peer Response Sessions Held On Networked Computers And Those Held In A FF Setting. Taiwan: National Center for Research on Teacher Learning.; Gentle, Op.cit.; Ballantyne, R., Hughes, K., \& Mylonas, A. (2002). Developing Procedures For Implementing Peer Assessment In Large Classes Using An Action Research Process. Assessment \& Evaluation in Higher Education, 27(5), 427-441.; Lejk, M., \& Wyvill, M. (2001). Peer-Assessment Of Contributions To A Group Project: A Comparison Of Holistic And Category-Based Approaches. Assessment \& Evaluation in Higher Education, 26(1), 61-72.)

${ }^{24}$ Gehringer, Op.cit.;

${ }^{25}$ Bozkurt, E., \& Demir, R. (2011). Öğrenci Görüşleri İle Akran Değerlendirme: Örnek Bir Uygulama. Proceedings of the 20. Ulusal Eğitim Bilimleri Kurultayl, Retrieved from http://www.pegem.net/akademi/kongrebildiri_detay.aspx?id=125034 
students had a positive consideration of the peer-evaluation and that it gave them the feeling of appreciation by others and that they found it fun as well. In addition, the peer-evaluation and self-evaluation helped students see and correct their mistakes and shortcomings. Gehringer ${ }^{26}$ emphasized that students completed the evaluation process with a minimal effort as they used web in their daily life constantly while Wen and Tsai ${ }^{27}$ stated that students had positive attitude to the practice and saw peer-evaluation as a facilitating tool which both support our findings.

This study showed that the web-based peer-evaluation and self-evaluation have aspects that can be criticized as well as positive aspects. The survey results indicated that there were few students who were disturbed by the peer-evaluation where their mistakes were noticed by their friends. In a study which supports this finding, it was stated that the peer-evaluation and self-evlauation may disturb students and have low reliability while results would be less correct and less useful ${ }^{28}$. Davies ${ }^{29}$ determined that knowing the identity of the person who was evaluated caused a negative impression in students, scoring became less objective and students had difficulty for that. In another study, it was stated that the identity of the scoring person should be hidden for a more realistic result and that this was an important point to be considered in future studies ${ }^{30}$.

Hansen $^{31}$ stated that traditional peer-evaluation, such as the one with pen and paper, created some differences when compared to respect to student participation, interpretation and attitude; while Huang ${ }^{32}$ stated that face-to-face evaluations included more interpretations and more participations. We need to emphasize that this different web-based view doesn't correspond to the findings and results of the present study. It was observed that the students weren't reluctant despite application of web-based program in schools was conducted in two stages. In addition, it was observed that students had high participation in surveys. Our findings are supported by the fact that students had high interest in learning the program,

${ }^{26}$ Gehringer, Op.cit:

${ }^{27}$ Wen and Tsai, Op.cit.;

${ }^{28}$ Falchikov, Op.cit.; Pond (as cited in Sluijsmans, D. (2002). Student Involvement In Assessment: The Training Of Peer Assessment Skills. Netherlands: Open University. p. 137); Tsivitanidou et al. , Op.cit.;

${ }^{29}$ Davies, Op.cit.;

${ }^{30}$ Ballantyne et.al. , Op.cit.; Lejk \& Wyvill, Op.cit.

${ }^{31}$ Hansen, J. G. (2005). Cooperative Learning Methods And The Teaching Of English Writing: Peer Response. Singapore, Singapore Tertiary English Teachers Society: STETS Language \& Communication Review.

${ }^{32}$ Huang, Op.cit. 
evaluating their friends and evaluating themselves and even they found the application enjoyable.

Successful evaluation applications depend on teachers as well as the quality of students, therefore, it was observed in this study that it was vital for the teachers to believe that the application would bring good results and to provide students with assistance during the learning process ${ }^{33}$. When we study the teacher survey data, we observed the needs of teachers to improve their skills for computer and the internet. Various ideas can be suggested for the function of teachers in such works where the competence of teachers in web-based applications. Gentle ${ }^{34}$ focuses on the reduction of teacher effect which is one of the alternative views on this matter. Gentle developed in 1994 an electronic system to see how correctly the students would evaluate themselves without a person supervising them. This system provided time savings, allowed students to make more than one evaluation and reduced teacher effect which makes it worth considering. This study concluded in teacher surveys that particularly the teachers above a certain age were distant from computers and the internet applications. Teachers themselves pointed out that they needed to receive information and training on this matter.

This study also measured the gender based achievement. The result in statistical data is that the girls are more successful than boys. Likewise, in one of the studies on revealing the relation of self-evaluation and peer-evaluation, it was concluded that girls were more successful in evaluation process ${ }^{35}$. In Yurdabakan's ${ }^{36}$ study of peer-evaluation with the $4^{\text {th }}$ grade students including 28 girls and 18 boys in the Social Sciences lesson, it was concluded that the evaluations of girls were closer to the evaluations of boys which supports the result of present study. On the other hand, Özeren ${ }^{37}$ conducted a meta-analysis study examining 68 theses, 16 papers and 44 articles between 2004-2011 years and stated that gender had a weak effect on the assessment and evaluation approaches which is a close finding to present study. Hence this study concluded that there was a slight difference between girls and boys.

${ }^{33}$ Lewkowicz \& Moon, Op.cit.

${ }^{34}$ Gentle, Op.cit.

35 Yurdabakan, İ. (2011). Yapılandırmacı Kuramın Değerlendirmeye Bakışı: Eğitimde Alternatif Değerlendirme Yöntemleri. Ankara Üniversitesi Eğitim Bilimleri Fakültesi Dergisi, 44(1), 51-77.

${ }^{36}$ Ibid.

${ }^{37}$ Özeren, E. (2013). Alternatif Ölçme Ve Değerlendirme Araçlari Üzerine Bir Meta Analiz Çalışması, Unpublished master thesis, Fırat Üniversitesi, Eğitim Bilimleri Enstitüsü, Elazı ̆̆. 


\subsection{SUGGESTIONS}

Web-based peer-evaluation and self-evaluation method has a positive effect on the achievement of students and therefore the web-based peer-evaluation and self-evaluation method remains as an area for researchers on achievement to further improve the method and to conduct further studies about it. Students find the web-based peer-evaluation and selfevaluation method easy, useful and enjoyable which offers an opportunity for students' interest and realization of learning. Teachers may use this method to motivate students to the lesson and to ensure active participation in the class. Having this study and similar studies in the curriculum is important to achieve the objective of education.

Web-based peer-evaluation and self-evaluation program applied the achievement aspect in state schools. Another study to be conducted in private schools may examine the effects of the program on achievement and attitudes. 


\section{REFERENCES}

Anderson, R. S. (1998). Why talk about different ways to grade? The shift from traditional assessment to alternative assessment. New Directions for Teaching and Learning (74), $5-16$.

Bahar, M. (2006). Geleneksel Alternatif Ölçme Ve Değerlendirme. Ankara: Pegem Yayınc1lik.

Ballantyne, R., Hughes, K., \& Mylonas, A. (2002). Developing Procedures For Implementing Peer Assessment In Large Classes Using An Action Research Process. Assessment \& Evaluation in Higher Education, 27(5), 427-441.

Bozkurt, E., \& Demir, R. (2011). Öğrenci Görüşleri İle Akran Değerlendirme: Örnek Bir Uygulama. Proceedings of the 20. Ulusal Eğitim Bilimleri Kurultayl, Retrieved from http://www.pegem.net/akademi/kongrebildiri_detay.aspx?id=125034

Creswell, J. W. (2012). Araştırma Deseni (S. B. Demir, Trans.). Ankara: Eğitim Kitap Yayıncılı̆̆ı.

Çepni, S. (2012). Araştırma Ve Proje Çalışmalarına Giriş. Trabzon: Celepler Matbaacılık.

Davies, P. (2000). Computerized Peer Assessment. Innovations in Education and Teaching International, 37(4), 346-355.

Falchikov, N. (1995). Peer Feedback Marking: Developing Peer Assessment. Innovations in Education \&Training International, 32(2), 175-187.

Gay, L. R., Mills, G. E., \& Airasian, P. (2009). Educational Research: Competencies For Analysis And Application ( $9^{\text {th }}$ ed.). USA: Pearson

Gehringer, E. (2001). Electronic Peer Review And Peer Grading In Computer-Science Courses. Proceedings Of The Thirty-Second Sigcse Technical Symposium On Computer Science Education (pp. 139-243). Raleigh.

Gentle, C. (1994). Thesis: An Expert System For Assessing Undergraduate Projects. In M. Thomas, T. Sechrest, \& N. Estes (Ed.), Deciding Our Future: Technological Imperatives For Education (pp. 1158-1160). Austin

Hansen, J. G. (2005). Cooperative Learning Methods And The Teaching Of English Writing: Peer Response. Singapore, Singapore Tertiary English Teachers Society: STETS Language \& Communication Review.

Huang, S. Y. (1998). A Comparison Between Chinese EFL Students' Peer Response Sessions Held On Networked Computers And Those Held In A FF Setting. Taiwan: National Center for Research on Teacher Learning.

Karasar, N. (2005). Bilimsel Araştırma Yöntemi. Ankara: Nobel Yayıncılık. 
Lejk, M., \& Wyvill, M. (2001). Peer-Assessment Of Contributions To A Group Project: A Comparison Of Holistic And Category-Based Approaches. Assessment \& Evaluation in Higher Education, 26(1), 61-72.

Lewkowicz, J., \& J. Moon. (1985). Evaluation: A Way Of Involving The Learner. In Evaluation: Lancaster Practical Papers In English Language Education (pp. 45-80). Oxford: Pergamon Press.

Lindblom-Ylanne, S., Pihlajamaki, H., \& Kotkas, T. (2006). Self, -Peer- And TeacherAssessment Of Student Essays. Active Learning In Higher Education, 1(7), 51-62.

Lu, J., \& Law, N. (2012). Online Peer Assessment: Effects Of Cognitive And Affective Feedback. Instructional Science, 40, 257-275.

Mcmillan, J. H., \& Schumacher, S. (2010). Research In Education: Evidence-based Inquiry. New York: Pearson Publishing.

Nartgün, Z. (2006). Fen Ve Teknoloji Öğretiminde Ölçme Ve Değerlendirme. In M. Bahar (Ed.), Fen ve Teknoloji Öğretimi (14. Bölüm). Ankara: Pegem A Yayıncılık.

Norcini, J. (2003). Peer Assessment Of Competence. Medical Education, 37(6), 539-543.

Özeren, E. (2013). Alternatif Ölçme Ve Değerlendirme Araçlari Üzerine Bir Meta Analiz Çalışması, Unpublished master thesis, Fırat Üniversitesi, Eğitim Bilimleri Enstitüsü, Elazığ.

Sluijsmans, D. (2002). Student Involvement In Assessment: The Training Of Peer Assessment Skills. Netherlands: Open University.

Sluijsmans, D., \& Prins, F. (2006). A conceptual framework for integrating peer assessment in teacher education. Studies in Educational Evaluation, 32(1), 6-22.

Sluijsmans, D., Dochy, F., \& Moerkerke, G. (1998). Creating A Learning Environment By Using Self, -Peer- And Co-Assessment. Learning Environment Research, 1, 293-319.

Steele, G. (2009). Self And Peer Assessment In An Undergraduate Communication Research Class Using Mixed Methods. Augustine Trinidad and Tobago: Department of Liberal Arts.

Turgut, M., \& Baykul, Y. (2012). Eğitimde Ölçme ve Değerlendirme. Ankara: Pegem Akademi.

Tsai, C. C., Liu, E. F., Lin, S., \& Yuan, S. M. (2001). A Networked Peer Assessment System Based On A Vee Heuristic. Innovations in Education and Teaching International, $38(3), 220-230$.

Tsivitanidou, O. E., Zacharias C. Z., \& Hovardas, T. (2011). Peer Versus Expert Feedback: An Investigation Of The Quality Of Peer Feedback Among Secondary School Students, Computers \& Education, 71, 133-152.

Wen, M., \& Tsai, C. C. (2006). University Students' Perceptions Of And Attitudes Toward (Online) Peer Assessment. Higher Education, 51, 27-44. 
Willey, K., \& Gardner, A. (2010). Investigating The Capacity Of Self And Peer Assessment Activities To Engage Students And Promote Learning. European Journal of Engineering Education, 35(4), 429-443.

Yurdabakan, İ. (2011). Yapılandırmacı Kuramın Değerlendirmeye Bakış1: Eğitimde Alternatif Değerlendirme Yöntemleri. Ankara Üniversitesi Eğitim Bilimleri Fakültesi Dergisi, 44(1), 51-77. 